\title{
PENERAPAN METODE RAD DALAM SISTEM RESERVASI DAN PENYEWAAN LAPANGAN FUTSAL SEBAGAI MEDIA PROMOSI DAN PENGOLAHAN INFORMASI
}

\author{
Agustiena Merdekawati[1]; Luci Kanti Rahayu[2], Dwi Cahyo Putra[3]
}

Program Studi Sistem Informasi[1] [2] [3]

Universitas Bina Sarana Informatika

agustiena.atd@bsi.ac.id[1], luci.lkr@bsi.ac.id[2], dcahyop19@gmail.com ${ }^{[3]}$

\begin{tabular}{|c|c|}
\hline INFO ARTIKEL & INTISARI \\
\hline $\begin{array}{l}\text { Diajukan : } \\
03 \text { Juli } 2021\end{array}$ & $\begin{array}{l}\text { Sistem yang digunakan pada Deltha Futsal masih manual, seperti dalam } \\
\text { melakukan pemasaran dan informasi promosi masih menggunakan brosur } \\
\text { dan spanduk, melakukan reservasi, ketersediaan lapangan dan menyewa }\end{array}$ \\
\hline $\begin{array}{l}\text { Diterima : } \\
25 \text { Juli } 2021\end{array}$ & $\begin{array}{l}\text { lapangan masih melalui telepon atau datang langsung, penginputan data } \\
\text { masih menggunakan buku dan kertas. Sehingga tidak efisien dan efektif. }\end{array}$ \\
\hline $\begin{array}{l}\text { Diterbitkan: } \\
01 \text { Desember } 2021\end{array}$ & $\begin{array}{l}\text { Dibuatnya website penyewaan lapangan futsal ini menggunakan metode } \\
\text { RAD (Research And Development) untuk pengembangan sistem. Dengan } \\
\text { adanya program ini dapat mempermudah para pengunjung agar tidak }\end{array}$ \\
\hline Kata Kunci : & perlu lagi datang ketempat untuk melakukan reservasi lapangan, \\
\hline $\begin{array}{l}\text { Lapangan Futsal, Promosi } \\
\text { RAD, Reservasi, Penyewaan }\end{array}$ & $\begin{array}{l}\text { mendapatkan informasi yang akurat dan tepat mengenai penyewaan } \\
\text { lapangan futsal, petugas dengan mudah mengontrol ketersediaan lapangan } \\
\text { dan mengelola transaksi, serta pemilik akan mudah dalam melihat laporan } \\
\text { transaksi sehingga meningkatkan efisien dan efektifitas dalam mengelola } \\
\text { transaksi penyewaan, mengurangi biaya pemasaran dan informasi yang } \\
\text { disampaikan dapat langsung diterima oleh masyarakat. }\end{array}$ \\
\hline
\end{tabular}

\section{PENDAHULUAN}

Perkembangan teknologi saat ini sudah semakin maju dengan memberikan hasil teknologi informasi dan komputer yang terus berkembang dan menjadi kebutuhan mendasar manusia. Pemanfaatan komputer sudah menjadi hal yang biasa yang digunakan secara rutin dan membantu setiap pekerjaan dalam memproses tugas-tugas yang penting yang berkaitan dengan data dalam jumlah yang kecil maupun besar. Semua kegiatan manusia dapat dikerjakan dengan mengunakan komputerisasi, bukan sekedar untuk mengetik dan bermain game, tetapi dapat digunakan untuk mencari informasi dan mengolah informasi yang dibutuhkan secara cepat, tepat, dan akurat. Sehingga banyak aplikasi yang dapat ditemukan baik berbayar maupun gratis dalam berbagai bidang, baik bidang industri, pendidikan, pariwisata, olahraga, dan sebagainya.

Dalam bidang olahraga, futsal sangat diminati oleh para masyarakat yang menyukai olahraga terutama olahraga sepak bola. Olahraga futsal menyerupai olahraga sepak bola, namun ada beberapa perbedaan seperti pemain pada futsal minimal 5 orang, sedangkan pada sepak bola berjumlah 11 orang, setiap babak pada futsal berdurasi 20 menit, sedangkan pada sepak bola berdurasi 45 menit (Adhikresna, 2021). Saat ini sudah banyak dijumpai penyewaan lapangan futsal, orang yang ingin bermain futsal dapat langsung mengunjungi tempat penyewaan lapangan futsal untuk memilih jenis lapangan yang ingin disewa.

Reservasi merupakan suatu bagian dari departemen yang berada paling depan yang memiliki tugas dan tanggung jawab menghandel permintaan pemesanan dari calon tamu, menurut Bagyono (Krestanto, 2019). Pada saat memutuskan hasil reservasi diterima atau tidak, petugas harus mengecek terlebih dahulu kesediaan lapangan sehingga sering terjadi kesalahan informasi dikarenakan petugas yang lupa mencatat reservasi sebelumnya, karena pencatatan yang masih menggunakan tulis tangan sehingga sulit ditemukannya data yang ingin dicari.

Sistem informasi penyewaan yang masih menggunakan cara manual, dengan memakai media kertas sebagai pengolahan transaksi penyewaan dan sarana menyimpan data. Jika dilakukan pencarian data, maka memerlukan waktu yang lama(Maimunah, Hariyansyah, \& Jihadi, 2017).

Sistem yang manual mengakibatkan keakuratan, ketepatan dan keefisienan menjadi kurang. Seperti contoh saat proses pemesanan menggunakan cara konvensional, untuk mengetahui informasi jadwal lapangan dan melakukan penyewaan lapangan, pelanggan harus datang langsung ke Sumber Jaya Futsal atau melalui telepon, kurangnya media promosi dan 
pencatatan transaksi masih menggunakan dalam buku besar, menurut Syakur dalam (Yuniva, Andriansah, \& Ikhsan, 2020).

Saat mempromosikan produknya ves boutique masih menggunakan metode yang kurang efisien. Melalui website dapat menjadikan media dalam melakukan promosi, informasi yang didalannya dapat membantu dalam memasarkan, dari segi biaya. Tenaga, dan waktu sehingga lebih efisien dan efektif dalam mengembangkan usaha ves boutique (Hasugian, 2018).

Penelitian ini mengenai penyewaan pada Deltha Futsal, Deltha Futsal berlokasi di daerah Bekasi. Deltha Futsal dalam melakukan promosi atau pemasaran masih menggunakan media brosur, spanduk, dan informasi dari mulut ke mulut, namun cara seperti itu tidak efektif karena memakan biaya dan ruang lingkup masyarakat yang mendapatkan info tersebut sangat terbatas. Selain itu, untuk melakukan reservasi lapangan, penyewa harus datang langsung ke Deltha Futsal, untuk mengetahui ketersediaan lapangan, pencatatan data reservasi pada Deltha Futsal masih menggunakan pencatatan dalam sebuah buku, sehingga dapat menyebabkan kesalahan pencatatan dan pencarian data yang terlalu lama, bukti transaksi masih ditulis dalam sebuah nota kertas atau kwitansi sehingga sering mengalami kehilangan nota atau kwitansi dan dapat mengakibatkan proses pembuatan laporan menjadi terhambat dan tidak akurat. Oleh karena permasalahan tersebut, Deltha Futsal perlu adanya bantuan sebuah website sebagai media promosi dan pengolahan informasi dalam bentuk penyewaan.

Dalam penelitian ini menggunakan menggunakan metode pengembangan sistem yang tepat dengan metode Research And Development (R\&D). Pada metode ini mengahasilkan suatu produk dan menguji efektifitas produk (Rumetna, Lina, \& Santoso, 2020). Perancangan sistem pada penelitian ini menggunakan UML, yaitu pemodelan visual yang dapat dipakai untuk mendefinisikan, menggambarkan, membangun, serta menarsipkan perangkat lunak (Ratnasari, Hadi, \& Budiarto, 2018).

\section{BAHAN DAN METODE}

Metode pengembangan sistem yang digunakan pada penelitian ini menggunakan model Research And Development (R\&D). Adapun tahap model RAD pada sistem reservasi dan penyewaan lapangan futsal ini ditampilkan pada gambar 1.

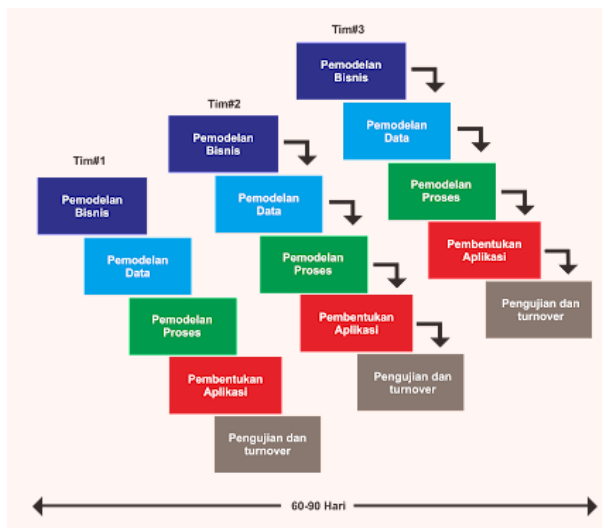

Sumber: (Sukamto, A. \& Shalahuddin, 2016) Gambar 1. Ilustrasi Model RAD

Berikut penjelasan tahap RAD pada penelitian ini sebagai berikut:

1. Pemodelan Bisnis

Tahap ini penulis melakukan pengamatan langsung ke Deltha Futsal dan mencari data yang dibutuhkan yang berkaitan dengan sistem reservasi lapangan futsal, sistem yang digunakan sebagai media promosi dan pengolahan informasi.

2. Pemodelan Data

Pada tahap ini penulis menggunakan ERD dan LRS untuk membuat model basis data, sehingga dengan model tersebut dapat diketahui atribut yang diperlukan dan hubungan antar datanya.

3. Pemodelan Proses

Untuk memodelkan proses bisnis, pada penelitian ini menggunakan usecase diagram dan activity diagram.

4. Pembuatan Aplikasi

Pada tahap ini penulis membuat program aplikas dengan menggunakan bahasa pemrograman PHP, HTM, dan CSS.

5. Pengujian dan Pergantian

Pada tahap ini penulis melakukan pengujian dengan menggunakan blackbox testing. Jika masih ditemukan ketidak sesuaian dengan yang diharapkan, makan akan dilakukan pergantian atau perubahan kembali.

Metode pengumpulan pada penelitian ini menggunakan beberapa cara, yaitu:

1. Observasi

Melakukan pencarian data dengan cara mengunjungi langsung Deltha Futsal, dengan mengamati dan ikut terlibat dalam proser reservasi dan penyewaannya

2. Wawancara

Bertanya langsung kepada petugas dan pemilik Lapangan Deltha Futsal, mengenai bagaiman proses transaksi, kendala apa saja, sampai kepada penyajian laporannya.

3. Studi Pustaka 
Melakukan pengumpulan data yang berkaitan dengan reservasi dan penyewaan lapangan futsal melalui buku-buku, jurnal, dan media internet.

\section{HASIL DAN PEMBAHASAN}

Hasil dari pembangunan sistem pada sistem reservasi dan penyewaan lapangan futsal pada Deltha futsal sebagai berikut:

1. Pemodelan Bisnis

Berdasarkan dari hasil analisa data yang dibutuhkan, maka terdapat tiga penggunayang mengakses sistem yaitu pengunjung, member, operator dan administrator.

a. Analisa kebutuhan pengunjung

1) Pengunjung dapat melihat informasi data lapangan

2) Pengunjung dapat melakukan registrasi

b. Analisa kebutuhan member

1) Member dapat melakukan login

2) Member dapat melihat ketersediaan lapangan dan harga lapangan

3) Member dapat melakukan reservasi dan menyewa lapangan

4) Member dapat melihat histori transaksi

5) Member dapat mengubah profil

c. Analisa kebutuhan operator

1) Operator melakukan login

2) Operator dapat mengelola transaksi (bagi pengunjung yang menyewa langsung datang ket Deltha Futsal)

3) Operator dapat mengelola data lapangan (tambah, hapus dan edit)

4) Operator dapat mengkonfirmasi pembayaran transaksi online

d. Analisa kebutuhan administrator

1) Administrator dapat melakukan login

2) Administrator dapat mengelola data lapangan

3) Administrator dapat mengelola data operator

4) Administrator dapat melihat histori penyewaan

5) Administrator dapat melihat laporan

2. Pemodelan Data

a. Entity Relationship Diagram (ERD)

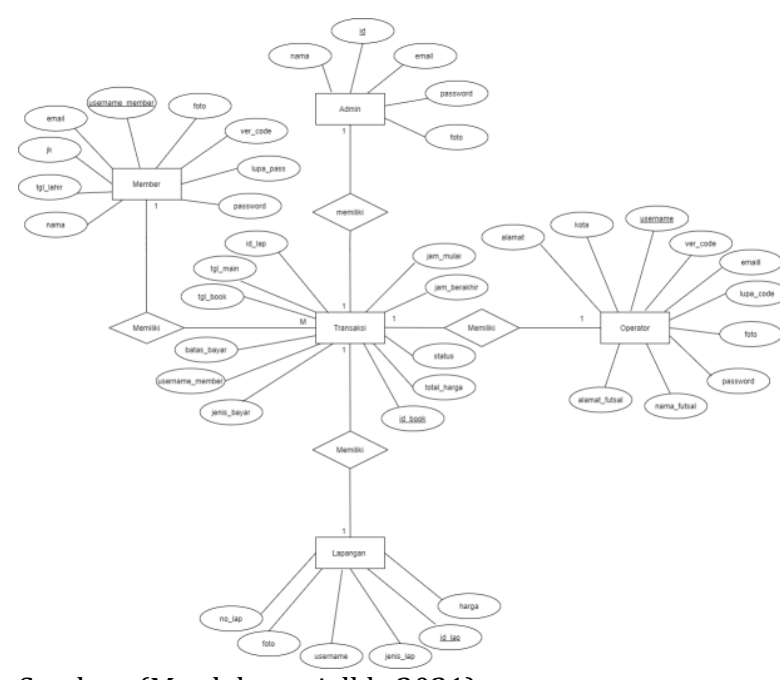

Sumber: (Merdekawati,dkk, 2021)

Gambar 2. ERD Sistem Reservasi dan Penyewaan

b. Logical Record Struktur (LRS)

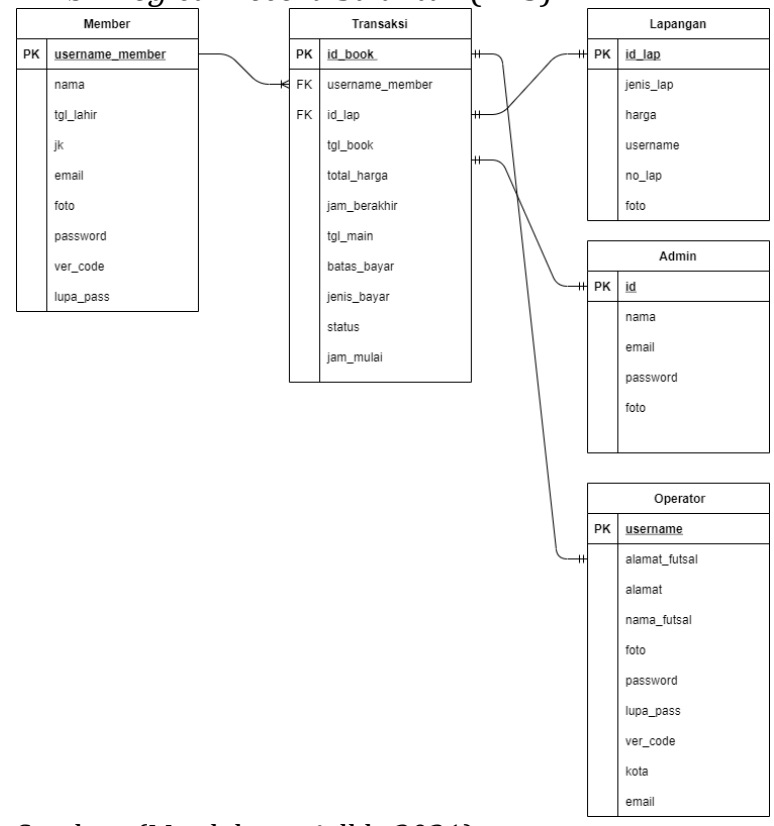

Sumber: (Merdekawati,dkk, 2021)

Gambar 3. LRS Sistem Reservasi dan Penyewaan

3. Pemodelan Proses

a. Usecase Diagram Pengunjung

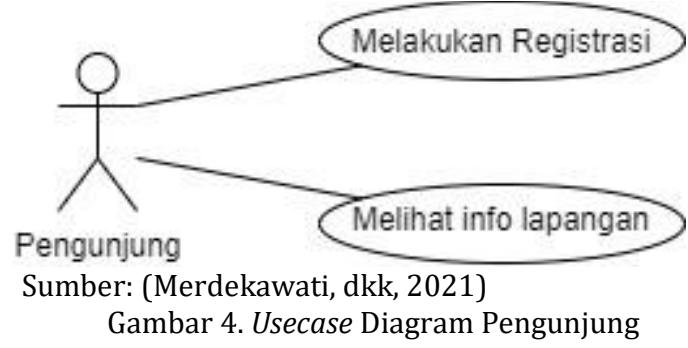

b. Usecase Diagram Member 


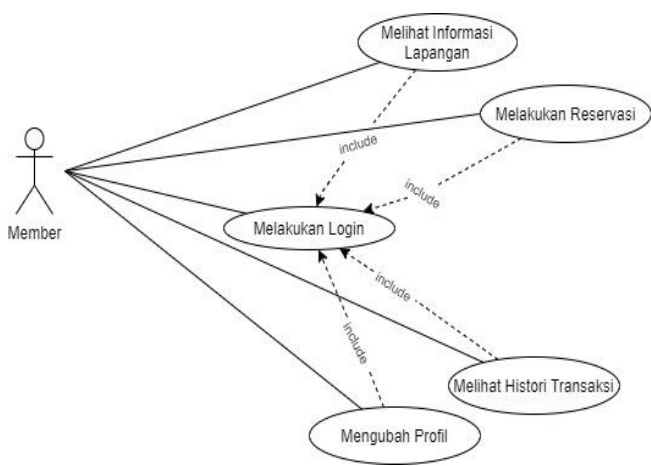

Sumber: (Merdekawati, dkk, 2021)

Gambar 5. Usecase Diagram Member

c. Usecase Diagram Operator

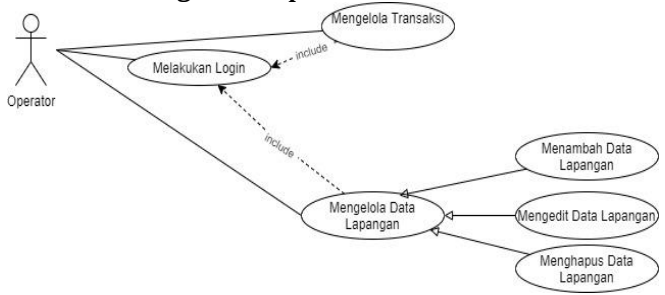

Sumber: (Merdekawati, dkk, 2021)

Gambar 6. Usecase Diagram Operator

d. Usecase Diagram Administrator

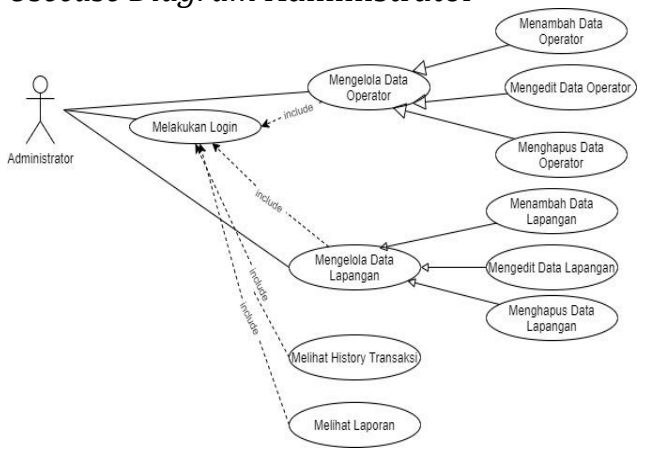

Sumber: (Merdekawati, dkk, 2021)

Gambar 7. Usecase Diagram Administrator

e. Activity Diagram Pengunjung

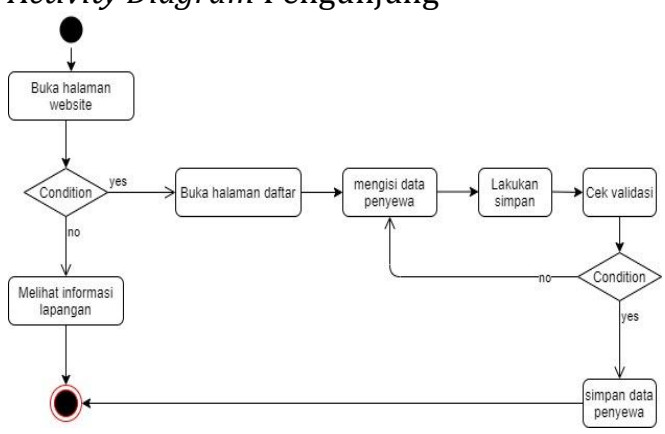

Sumber: (Merdekawati, dkk, 2021)

Gambar 8. Activity Diagram Pengunjung

f. Activity Diagram Member

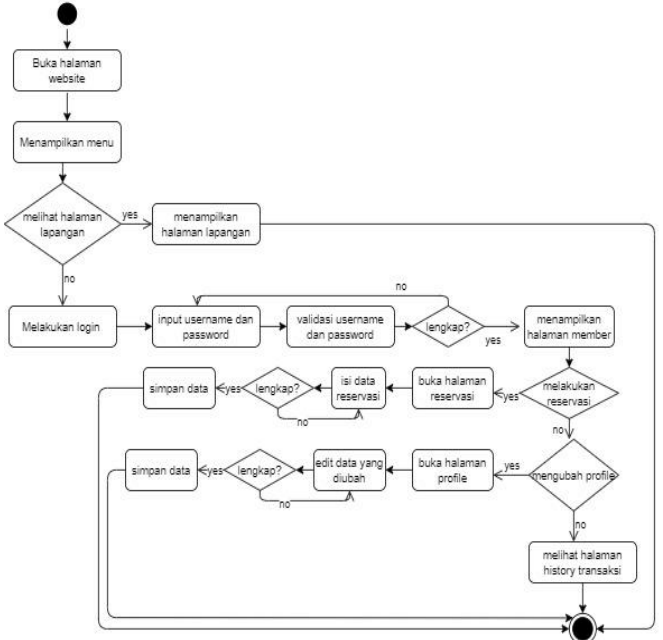

Sumber: (Merdekawati, dkk, 2021) Gambar 9. Activity Diagram Member

g. Activity Diagram Operator
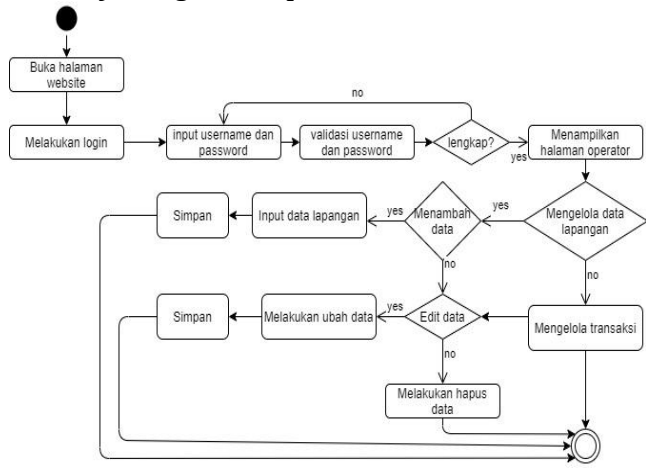

Sumber: (Merdekawati, dkk, 2021)

Gambar 10. Activity Diagram Member

h. Activity Diagram Administrator

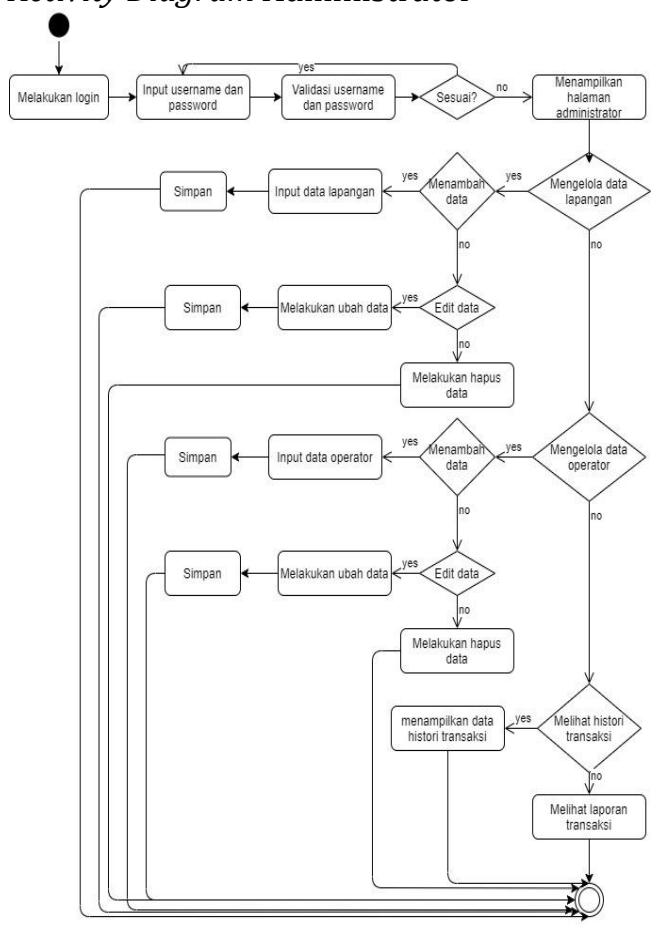

Sumber: (Merdekawati, dkk, 2021) 
Gambar 11. Activity Diagram Member

4. Pembuatan Aplikasi

a. Halaman Reservasi Lapangan Futsal

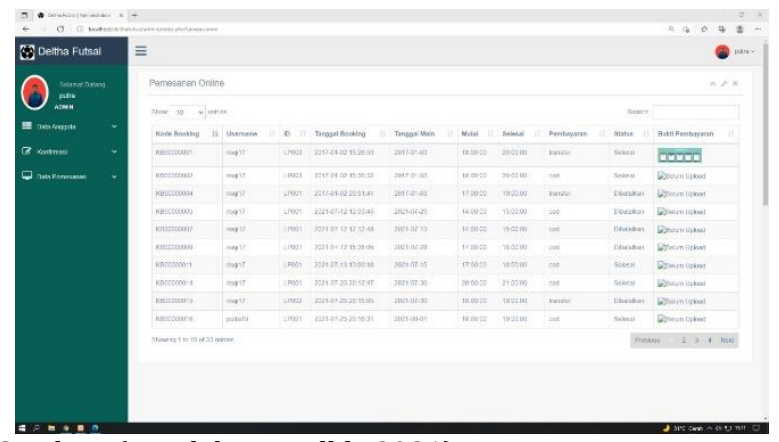

Sumber: (Merdekawati,dkk, 2021)

Gambar 12. Tampilan Halaman Reservasi Lapangan

b. Halaman Penyewaan Lapangan Futsal

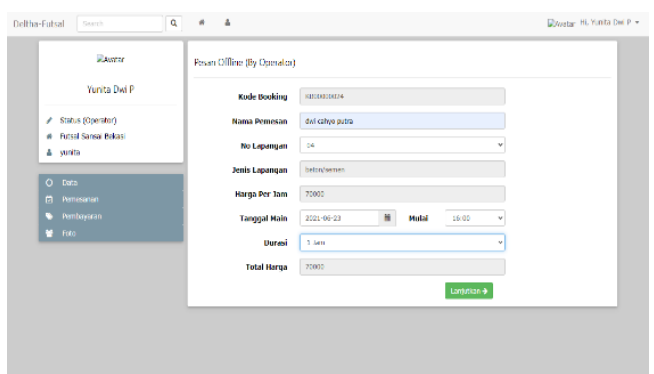

Sumber: (Merdekawati,dkk, 2021)

Gambar 13. Tampilan Halaman Penyewaan Lapangan

c. Halaman Laporan Penyewaan Lapangan Futsal

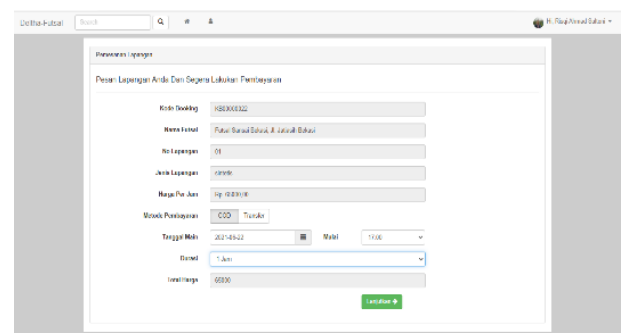

Sumber: (Merdekawati, dkk, 2021)

Gambar 14. Tampilan Halaman Laporan Penyewaan

5. Pengujian dan Pergantian

Pengujian program yang telah dibuat menggunakan blackbox testing yang menguji proses masukan program. Berikut pengujian halaman reservasi dan penyewaan lapangan futsal
Tabel 1. Blackbox Testing Halaman Reservasi

\begin{tabular}{|c|c|c|c|c|c|}
\hline $\begin{array}{l}\mathbf{N} \\
\mathbf{o}\end{array}$ & $\begin{array}{c}\text { Skenario } \\
\text { pengujian }\end{array}$ & $\begin{array}{l}\text { Test } \\
\text { case }\end{array}$ & $\begin{array}{l}\text { Hasil yang } \\
\text { diharapkan }\end{array}$ & $\begin{array}{l}\text { Hasil } \\
\text { peng } \\
\text { ujian }\end{array}$ & $\begin{array}{l}\text { Kesim } \\
\text { pulan }\end{array}$ \\
\hline 1. & $\begin{array}{l}\text { Tidak } \\
\text { Memilih } \\
\text { metode } \\
\text { pembayaran, } \\
\text { tanggal main } \\
\text { dan mulai, } \\
\text { durasi tidak } \\
\text { diisi } \\
\text { kemudian } \\
\text { klik tombol } \\
\text { Lanjutkan }\end{array}$ & $\begin{array}{l}\text { pemba } \\
\text { yaran : } \\
\text { (koson } \\
\text { g) } \\
\text { tangga } \\
\text { l main } \\
\text { dan } \\
\text { mulai : } \\
\text { (koson } \\
\text { g) } \\
\text { durasi } \\
\text { (koson } \\
\text { g) }\end{array}$ & $\begin{array}{l}\text { Sistem akan } \\
\text { menolak } \\
\text { akses user } \\
\text { dan } \\
\text { menampilka } \\
\text { n "Please } \\
\text { select one of } \\
\text { these option } \\
\text { and Please } \\
\text { fill out this } \\
\text { field" }\end{array}$ & $\begin{array}{l}\text { Sesu } \\
\text { ai } \\
\text { hara } \\
\text { pan }\end{array}$ & Valid \\
\hline 2. & $\begin{array}{l}\text { Memilih } \\
\text { metode } \\
\text { pembayaran, } \\
\text { tanggal main } \\
\text { dan } \\
\text { mulai,durasi } \\
\text { tidak diisi } \\
\text { kemudian } \\
\text { klik tombol } \\
\text { Lanjutkan }\end{array}$ & $\begin{array}{l}\text { Pemba } \\
\text { yaran : } \\
\text { Transf } \\
\text { er } \\
\text { Tangg } \\
\text { al } \\
\text { main } \\
\text { dan } \\
\text { mulai : } \\
\text { (koson } \\
\text { g) } \\
\text { Durasi } \\
: \\
\text { (koson } \\
\text { g) }\end{array}$ & $\begin{array}{l}\text { Sistem akan } \\
\text { menolak } \\
\text { akses user } \\
\text { dan } \\
\text { menampilka } \\
\text { n "Please fill } \\
\text { out this } \\
\text { field" }\end{array}$ & $\begin{array}{l}\text { Sesu } \\
\text { ai } \\
\text { hara } \\
\text { pan }\end{array}$ & Valid \\
\hline 3 & $\begin{array}{l}\text { Memilih } \\
\text { metode } \\
\text { pembayaran, } \\
\text { mengisi } \\
\text { tanggal main, } \\
\text { dan tidak } \\
\text { mengisi } \\
\text { mulai ,durasi } \\
\text { tidak diisi } \\
\text { kemudian } \\
\text { klik tombol } \\
\text { Lanjutkan }\end{array}$ & $\begin{array}{l}\text { Pemba } \\
\text { yaran : } \\
\text { Transf } \\
\text { er } \\
\text { Tangg } \\
\text { al } \\
\text { main : } \\
30-06- \\
2021 \\
\text { mulai : } \\
\text { (koson } \\
\text { g) } \\
\text { Durasi } \\
: \\
\text { (koson } \\
\text { g) }\end{array}$ & $\begin{array}{l}\text { Sistem akan } \\
\text { menolak } \\
\text { akses user } \\
\text { dan } \\
\text { menampilka } \\
\text { n } \\
\text { "Please fill } \\
\text { out this } \\
\text { field" }\end{array}$ & $\begin{array}{l}\text { Sesu } \\
\text { ai } \\
\text { hara } \\
\text { pan }\end{array}$ & Valid \\
\hline 4 & $\begin{array}{l}\text { Memilih } \\
\text { metode } \\
\text { pembayaran, } \\
\text { mengisi } \\
\text { tanggal main, } \\
\text { dan mengisi } \\
\text { mulai ,durasi } \\
\text { tidak diisi } \\
\text { kemudian } \\
\text { klik tombol } \\
\text { Lanjutkan }\end{array}$ & $\begin{array}{l}\text { Pemba } \\
\text { yaran : } \\
\text { Transf } \\
\text { er } \\
\text { Tangg } \\
\text { al } \\
\text { main : } \\
30-06- \\
2021 \\
\text { mulai : } \\
16.00 \\
\text { Durasi } \\
: \\
\text { (koson } \\
\text { g) }\end{array}$ & $\begin{array}{l}\text { Sistem akan } \\
\text { menolak } \\
\text { akses user } \\
\text { dan } \\
\text { menampilka } \\
\text { n } \\
\text { "Please fill } \\
\text { out this } \\
\text { field" }\end{array}$ & $\begin{array}{l}\text { Sesu } \\
\text { ai } \\
\text { hara } \\
\text { pan }\end{array}$ & Valid \\
\hline 5 & $\begin{array}{l}\text { Memilih } \\
\text { metode } \\
\text { pembayaran, } \\
\text { mengisi } \\
\text { tanggal main, } \\
\text { dan mengisi } \\
\text { mulai ,durasi } \\
\text { diisi } \\
\text { kemudian }\end{array}$ & $\begin{array}{l}\text { Pemba } \\
\text { yaran : } \\
\text { Transf } \\
\text { er } \\
\text { Tangg } \\
\text { al } \\
\text { main : } \\
\text { 30-06- }\end{array}$ & $\begin{array}{l}\text { Sistem } \\
\text { menerima } \\
\text { akses login } \\
\text { dan } \\
\text { kemudian } \\
\text { langsung } \\
\text { menampilka } \\
\text { n menu } \\
\text { pembyaran }\end{array}$ & $\begin{array}{l}\text { Sesu } \\
\text { ai } \\
\text { hara } \\
\text { pan }\end{array}$ & Valid \\
\hline
\end{tabular}




\begin{tabular}{|c|c|l|l|l|l|}
\hline $\begin{array}{c}\text { N } \\
\mathbf{0}\end{array}$ & $\begin{array}{c}\text { Skenario } \\
\text { pengujian }\end{array}$ & $\begin{array}{l}\text { Test } \\
\text { case }\end{array}$ & $\begin{array}{c}\text { Hasil yang } \\
\text { diharapkan }\end{array}$ & $\begin{array}{c}\text { Hasil } \\
\text { peng } \\
\text { ujian }\end{array}$ & $\begin{array}{c}\text { Kesim } \\
\text { pulan }\end{array}$ \\
\hline & klik tombol & $\begin{array}{l}2021 \\
\text { mulai : }\end{array}$ & & & \\
& Lanjutkan & $\begin{array}{l} \\
16.00 \\
\text { Durasi } \\
: \\
\end{array}$ & & & \\
& & & & \\
& & & & \\
\hline
\end{tabular}

\section{KESIMPULAN}

Saat ini sistem reservasi dan penyewaan lapangan futsal pada Deltha Futsal masih menggunakan tulis tangan sehingga ditemukannya beberapa masalah. Dengan di bangunnya sistem reservasi dan penyewaan yang menggunakan website dapat mempermudah para pengunjung agar tidak perlu lagi datang ketempat untuk melakukan reservasi lapangan, mendapatkan informasi yang akurat dan tepat mengenai penyewaan lapangan futsal, petugas dengan mudah mengontrol ketersediaan lapangan dan mengelola transaksi, serta pemilik akan mudah dalam melihat laporan transaksi sehingga meningkatkan efisien dan efektifitas dalam mengelola transaksi penyewaan, mengurangi biaya pemasaran dan informasi yang disampaikan dapat langsung diterima oleh masyarakat.

\section{REFERENSI}

Adhikresna, M. J. (2021). Perbedaan Sepak Bola dan Futsal. Retrieved from https://www.kompas.com/sports/read/202 1/04/13/13200018/perbedaan-sepak-boladan-futsal?page $=$ all

Hasugian, P. S. (2018). Perancangan Website Sebagai Media Promosi Dan Informasi. Journal of Informatic Pelita Nusantara, 3(1), 82-86.

Krestanto, H. (2019). Strategi Dan Usaha Reservasi Untuk Meningkatkan Tingkat Hunian Di Grand Orchid Hotel Yogyakarta. Media Wisata, https://doi.org/10.31219/osf.io/2q53k

Maimunah, Hariyansyah, \& Jihadi, G. (2017). Rancang Bangun Sistem Aplikasi Penyewaan Lapangan Futsal Berbasis Web. Seminar Nasional Teknologi Informasi Dan Multimedia 2017 STMIK AMIKOM Yogyakarta, 4 Februari 2017 ISSN 2302-3805, 7-12.

Ratnasari, D., Hadi, H. F., \& Budiarto, J. (2018). RANCANG BANGUN APLIKASI PENYEWAAN LAPANGAN FUTSAL BERBASIS ANDROID. JUTI: Jurnal Ilmiah Teknologi Informasi,
$16(2)$

Rumetna, M. S., Lina, T. N., \& Santoso, A. B. (2020). Rancang Bangun Aplikasi Koperasi Simpan Pinjam Menggunakan Metode Research and Development. Simetris: Jurnal Teknik Mesin, Elektro Dan Ilmu Komputer, 11(1), 119-128. https://doi.org/10.24176/simet.v11i1.3731

Sukamto, A., R., \& Shalahuddin, M. (2016). Rekayasa Perangkat Lunak. Bandung: Informatika Bandung.

Yuniva, I., Andriansah, \& Ikhsan, Y. N. (2020). PERANCANGAN APLIKASI WEB PENYEWAAN LAPANGAN FUTSAL (STUDI KASUS : SUMBER JAYA FUTSAL TANGERANG). Bianglala Informatika, 8(1), 31-35. 